\title{
When Grief and Crises Intersect: Perspectives of a Black Physician in the Time of Two Pandemics
}

\author{
Kimberly D Manning, MD
}

Department of Medicine, Emory University, Atlanta, Georgia.

"Hey there-just checking on you and letting you know I'm thinking of you."

"I know words don't suffice right now. You are in my thoughts."

"If there's any way that I can be of support or if there's something you need, just let me know."

The texts and emails have come in waves. Pinging into my already distracted headspace when, like them, I'm supposed to be focused on a Zoom or WebEx department meeting. These somber reminders underscore what I have known for years but struggled to describe with each new "justice for" hashtag accompanying the name of the latest unarmed Black person to die. This is grief.

With every headline in prior years, as Black Americans we have usually found solace in our collective fellowship of suffering. Social media timelines become flooded with our own amen choirs and outrage along with words of comfort and inspiration. We remind ourselves of the prior atrocities survived by our people. And like them, we vow to rally; clinging to one another and praying to make it to shore. Though intermittently joined by a smattering of allies, our suffering has mostly been a private, repetitive mourning.

\section{THE TWO PANDEMICS}

The year 2020 ushered in a new decade along with the novel SARS-CoV2 (COVID-19) global pandemic. In addition to the thousands of lives that have been lost in the United States alone, COVID-19 brought with it a disruption of life in ways never seen by most generations. Schools and businesses were closed to mitigate spread. Mandatory shelter-in-place orders coupled with physical distancing recommendations limited human interactions and cancelled everything from hospital visitations to graduations, intergenerational family gatherings, conferences, and weddings. ${ }^{1}$ As the data expanded, it quickly became apparent that minorities, particularly Black Americans, shouldered a disproportionate burden of COVID-19. ${ }^{2}$ Known health disparities were amplified.

While caring for our patients as Black physicians in the time

Corresponding Author: Kimberly D Manning MD; Email: kdmanni@emory.edu; Twitter: @gradydoctor.

Published online first June 5, 2020

Received: June 3, 2020; Accepted: June 3, 2020

(c) 2020 Society of Hospital Medicine DOI 10.12788/jhm.3481 of coronavirus, silently we mourned again. The connection and trust once found through racial concordance was now masked figuratively and literally by personal protective equipment (PPE). We ignored the sting of intimations that the staggering numbers of African Americans hospitalized and dying from COVID-19 could be explained by lack of discipline or, worse, genetic differences by race. Years of disenfranchisement and missed economic opportunities forced large numbers of our patients and loved ones out on the front lines to do essential jobs-but without the celebratory cheers or fanfare enjoyed by others. Frantic phone calls from family and acquaintances interrupted our quiet drives home from emotionally grueling shifts in the hospital-each conversation serving as our personal evidence of COVID-19 and her ruthless ravage of the Black community. Add to this trying to serve as cultural bridges between the complexities of medical distrust and patient advocacy along with wrestling with our own vulnerability as potential COVID-19 patients, these have been overwhelming times to say the least.

Then came the acute decompensation of the chronic racism we'd always known in the form of three recent killings of more unarmed African Americans. On March 13, 2020, 26-yearold Breonna Taylor was shot after police forcibly entered her home after midnight on a "no knock" warrant. ${ }^{3}$ The story was buried in the news of COVID-19-but we knew. Later we'd learn that 26-year-old Ahmaud Arbery was shot and killed by armed neighbors while running through a Brunswick, Georgia, neighborhood. His death on February 23, 2020, initially yielded no criminal charges. ${ }^{4}$ Then, on May 25, 2020, George Floyd, a 46-year-old father arrested for suspected use of a counterfeit $\$ 20$ bill, died after a law enforcement official kneeled with his full body weight upon Floyd's neck for over 8 minutes. ${ }^{5}$ The deaths of Arbery and Floyd were captured by cell phone cameras which, aided by social media, quickly reached the eyes of the entire world.

At first, it seemed plausible that this would be like it always has been. A Black mother would stand before a podium filled with multiple microphones crying out in anguish. She would be flanked by community leaders and attorneys demanding justice. Hashtags would be formed. Our people would stand up or kneel down in solidarity_-holding fast to our historic resilience. Evanescent allies would appear with signs on lawns and held high over heads. A few weeks would pass by and things would go back to normal. Black people would be left with what always remains: heads bowed and praying at dinner tables petitioning a higher power for protection followed by 
reaffirmations of what, if anything, could be done to keep our own mamas away from that podium. We've learned to treat the grief of racism as endemic to us alone, knowing that it has been a pandemic all along.

\section{A TIME OF RECKONING}

The intersection of the crisis of the COVID-19 pandemic, complete with its social isolation and inordinate impact on minorities, and the acuity of the grief felt by the most recent events of abject racism have coalesced to form what feels like a pivotal point in the arc of justice. Like the bloated, disfigured face of lynched teenager Emmett Till lying lifeless in an open casket for the entire world to see in 1955, ${ }^{6}$ footage of these recent deaths typify a level of inhumanity that makes it too hard to turn away or carry on in indifference. The acute-on-chronic grief of racism felt by African Americans has risen into a tsunami, washing open the eyes of privileged persons belonging to all races, ethnicities, faiths, socioeconomic backgrounds, political views, and ages. The bulging neck veins, crackles, and thumping gallop rhythm of our hidden grief has declared itself: The rest of the world now knows that we can't breathe.

Our moral outrage is pushing us to do something. Marches and demonstrations have occurred in nearly every major city. For those historically disenfranchised and let down by our societal contract, grief has, at times, met rage. Though we all feel an urgency, when we try to imagine ways to dismantle racism in the US it seems insurmountable. But as hospitalists and leaders, we will face black patients, colleagues, and neighbors navigating the pain of this exhausting collective trauma. While we won't have all the answers immediately, we recognize the peculiar intersection between the COVID-19 crisis and the tipping point of grief felt by Black people with the recent deaths of Ahmaud Arbery, Breonna Taylor, and George Floyd, and it urges us to try.

\section{Where can we start?}

This is a time of deep sorrow for Black people. Recognizing it as such is an empathic place to begin. Everyone steers through grief differently, but a few things always hold true:

- Listen more than you talk-even if it's uncomfortable. This isn't a time to render opinions or draw suffering comparisons.

- Timely support is always appreciated. Leaders should feel the urgency to speak up early and often. Formal letters from leadership on behalf of organizations may feel like an echo chamber but they are worth the effort. Delays can be misun- derstood as indifference and make the pain worse.

- The ministry of presence does not have to be physical. Those awkward text messages and emails create psychological safety in your organization and reduce loneliness. They also afford space to those who are still processing emotions and would prefer not to talk.

- Don't place an expectation on the grieving to guide you through ways to help them heal. Though well-meaning, it can be overwhelming. This is particularly true in these current times.

- When in doubt, remember that support is a verb. Ultimately, sustained action or inaction will make your position clearer than any text message or email. Be sensitive to the unique intricacy of chronicity and missed opportunity when talking about racism.

Along with the pain we all feel from the impact of COVID-19, this is the time to recognize that your African American colleagues, patients, and friends have been navigating another tenacious and far more destructive pandemic at the same time. It is acute. It is chronic. It is acute-on-chronic. Perhaps 2020 will also be remembered for the opportunity it presented for the centuries old scourge of racism to no longer be our transparent cross to bear alone. Unlike COVID-19, this pandemic of racism is not "unprecedented." We have been here before. It's time we all grieve-and act-together.

Disclosure: The author has nothing to disclose.

\section{References}

1. COVID-19: Statewide Shelter in Place Order. Accessed June 2, 2020. https:// georgia.gov/covid-19-state-services-georgia/covid-19-statewide-shelterplace-order

2. Garg S, Kim L, Whitaker M, et al. Hospitalization Rates and Characteristics of Patients Hospitalized with Laboratory-Confirmed Coronavirus Disease 2019_COVID-NET, 14 States, March 1-30, 2020. MMWR Morb Mortal Wkly Rep. 2020;69:458-464. http://dx.doi.org/10.15585/mmwr.mm6915e3

3. Oppel RA Jr. Here's what you need to know about Breonna Taylor's death. May 30, 2020. New York Times. Accessed June 2, 2020. https://www.nytimes. com/article/breonna-taylor-police.html

4. Fausset R. What we know about the shooting death of Ahmaud Arbery. New York Times. May 22, 2020. Accessed June 2, 2020. https://www.nytimes.com/ article/ahmaud-arbery-shooting-georgia.html

5. Hill E, Tiefenthäler, Triebert C, Jordan D, Willis H, Stein R. 8 minutes and 46 seconds: how George Floyd was killed in police custody. May 31, 2020. Accessed June 2, 2020. New York Times. https://www.nytimes.com/2020/05/31/ us/george-floyd-investigation.html

6. Pilkington E. Will justice finally be done for Emmett Till? Family hope a 65year wait may soon be over. April 25, 2020. The Guardian. Accessed June 2, 2020. https://www.theguardian.com/us-news/2020/apr/25/emmett-till-longwait-for-justice 